\title{
Strategy to Improve the Listening Behaviour and Extent of Participation of Sangham Community Radio Listeners
}

\author{
K. Aruna*, V. Sudha Rani and A. Sailaja \\ Department of Agricultural Extension, PJTSAU, Hyderabad, Telangana - 500032, India \\ *Corresponding author
}

\section{A B S T R A C T}

\begin{tabular}{|l|}
\hline Key w o r d s \\
$\begin{array}{l}\text { Community radio, } \\
\text { Listening } \\
\text { behaviour, Extent of } \\
\text { participation }\end{array}$ \\
\hline Article Info \\
\hline $\begin{array}{l}\text { Accepted: } \\
\text { 25 May } 2018 \\
\text { Available Online: } \\
\text { 10 June } 2018\end{array}$ \\
\hline
\end{tabular}

\section{Introduction}

Among the various mass media communication, radio is one, which possesses a quality of conveying the advanced information quickly and promptly. It can be used effectively to reach large number of people inexpensively in a short time. Community radio is a type of radio service that caters to the interests of a certain area, broadcasting material that is popular to a local audience. Modern day community radio stations serve their listeners by offering a variety of location specific content that is not provided by the larger commercial radio stations. Community radio outlets may carry news and information geared towards the local area, particularly immigrant or minority groups that are poorly served by other major media outlets.

The Sangham community based radio station licenced to Deccan Development Society (NGO) in Andhra Pradesh was launched on $15^{\text {th }}$ October, 2008 in Machnoor village, Medak district and was switched on at 11.00am. Sangham radio broadcasts on $90.4 \mathrm{MHz}$. The basic idea behind the station is to reach the farmers to address their problems and transfer technologies. The station has become the platform for the languages, voices and views of local farmers and addresses all 
the issues concerning farmers as well as farming. Hence, an attempt has been made to suggest a strategy to improve the listening behaviour and extent of participation of community radio listeners.

\section{Materials and Methods}

An Ex-post facto research design was adopted in the present investigation. The research study was conducted in Medak district during 2009-10. The Sangham Community Radio covers 4 mandals in Medak district namely Zaheerabad, Jharasangam, Raikode and Nyalkal. From each mandal, three villages were selected at random by following sequential systematic random sampling method. Thus a total of twelve villages were selected for the study.

Ten respondents from each village were selected randomly using lottery method, thus making a total of 120 respondents.

In view of very less extent of participation and listening behavior a strategy was developed to improve their listening behaviour and extent of participation by collecting data from the respondents. Hence the present investigation was focused on designing a strategy to improve the listening behaviour and extent of participation of community radio listeners.

\section{Results and Discussion}

A strategy was developed based on the responses of community radio listeners to improve the listening behavior and extent of participation in community radio programmes. The strategy includes the administrative, technical, organizational and financial strategies to be taken up by the Deccan Development Society(DDS) and the programme staff of the community radio.

\section{Strategies to improve the listening behavior}

\section{Administrative strategies}

As majority of the community radio listeners were unable to listen the programmes due to lack of sound clarity. So, the Deccan Development Society (DDS) should install new signal transmitting towers where the villages are located away from the radio station for improving the sound clarity.

\section{Technical strategies}

Programme staff of community radio station should conduct training programmes to the participants about development of community radio programmes and suggested them to repeat the important points at the end of the programme, provide the information with regard to inputs, choose the specific and best alternative and about time management of the programme.

As paatalu (folk songs) programme was most regularly listened, programme staff should take initiative to broadcast paradies of folk songs with agricultural information as content of the song.

As some of the listeners felt that, the duration of community radio broadcasts was inadequate. So, the programme staff of community radio staff should increase the duration of each programme on an average by 5 minutes for each programme.

Majority of the respondents did not meet the agricultural officers and scientists for getting information. So, agricultural officers and scientists of SAU should be involved and provide the information through community radio to suggest listeners best solution. Because, 97.5 per cent of the respondents listen to community radio regularly.

Programme staff of community radio station should broadcast the programmes in the form of burrakatha and harikatha (traditional folk formats). 
Radio station staff should announce the weekly programmes on the first day of week.

Programme staff of community radio station should broadcast the youth related programmes on self employment and Agri entrepreneurship to create interest among the young age respondents.

Community radio programmes are being broadcasted in the evening from $7 \mathrm{pm}$ to $9 \mathrm{pm}$. Programme staff of community radio station should prepone the community radio programmes to broadcast half-an-hour before i.e., $6.30 \mathrm{pm}$ to $8.30 \mathrm{pm}$, as per the suggestion given by the participants.

\section{Organizational strategies}

Programme staff of community radio station should form the groups of community radio listeners based on occupation, crops and interest for getting effective feedback about the community radio programmes, which will facilitate effective designing and development of community radio programmes.

\section{Strategies to improve the extent of participation}

\section{Administrative strategies}

Deccan Development Society (DDS) should provide transport facilities to the participants for in time participation in the community radio programmes.

As most of the participants are illiterates, they are facing the problem in participating and in developing the programmes. So, Deccan Development society (DDS) should arrange night school for educating the respondents.

Deccan Development Society (DDS) should appoint staff with agricultural background for giving suggestions to participants for presenting effectively in manavuri pantalu programme.

\section{Technical strategies}

Programme staff of community radio station should broadcast the youth related programmes to create and sustain interest among the young age respondents, as their extent of participation found to be more.

Programme staff of community radio station should conduct the meetings to encourage the more experienced farmers to participate in community radio programmes.

The radio programmes should address the participants with high socio-politico participation as they are popular with the farmers and can influence them to adopt new technologies. So, programme staff should take care in developing the community radio programmes, addressing those who have more socio-political participation.

Programme staff of community radio station should conduct the meeting to the participants about the importance of group programmes and how to improve the co-ordination among the participants.

\section{Financial strategies}

As majority of participants felt that they are getting less remuneration for their participation. So, the Deccan Development Society (DDS) should provide adequate funds to community radio station to increase the remuneration and provide transport facilities to the participants, to encourage participation by community people more in community radio programmes.

In conclusion, strategy is the contributing of various plans, the Deccan Development Society (DDS) and programme staff of community radio should focused on to minimize the problems, which were faced by community radio listeners in listening and participation in community radio programmes. The administrative, technical, 
organizational and financial strategies may be improve the listening and extent of pariticiaption of community radio listeners in community radio programmes.

\section{References}

Agwu A E, Ekwueme J N and Anyanwu A C 2008 Adoption of improved agricultural technologies disseminated via radio farmer programme by farmers in Enugu state, Nigeria.
African Journal of Biotechnology 7(9): 1277-1286.

Bhosle P B, Jondhale S G and Kadam K P 2006 Effectiveness of farm broadcast in transfer of agricultural technology. Farm communication through mass media in the new millemium pp 19-27. Krishnamurthy A T, Nataraju M S and Naik S C 2009 Study on problems and suggestions of audience towards farm broadcast and telecast programmes. Mysore Journal of Agricultural Sciences 43 (1): 122-129.

\section{How to cite this article:}

Aruna, K., V. Sudha Rani and Sailaja, A. 2018. Strategy to Improve the Listening Behaviour and Extent of Participation of Sangham Community Radio Listeners. Int.J.Curr.Microbiol.App.Sci. 7(06): 3535-3538. doi: https://doi.org/10.20546/ijcmas.2018.706.415 